\title{
Evaluation and Application of New-Semarang Coastal Resources Management
}

\author{
Alin Fithor*, Slamet Budi Prayitno, Frida Purwanti and Agus Indarjo \\ Faculty of Fisheries and Marine Science, Diponegoro University, Semarang 50275, Indonesia
}

\begin{abstract}
The beach in Semarang's city has a variety of uniqueness with a variety of types and potential. The beach located on the north coast of Semarang city has various characteristics and strengths, and weaknesses. In overcoming differences in management and avoiding misunderstandings between governments, it prioritizes managing the coastal location. At least four integrated coastal management sub-systems consist of Human Resources Management, Accessibility, Beach Location Infrastructure, and Management Policies. This research was conducted from April 2020 until August 2020, to determine the most appropriate alternative strategy to be chosen and implemented in coastal location management. Study analysis with an Analytical Hierarchy Process-AHP analytical technique use with Application R - Open sources. The integrated coastal area management can as the most appropriate coastal location management strategy to implement the current situation and future planning. Alternative methods planned for use are the Availability of a Security Guard, Ease of Access with Signage, Parking Lots, and Rule or regulations to an Integrated Location. The study results stated that the best strategy is management collaboration in the form of interrelated rules.
\end{abstract}

Keywords: Analytical hierarchy process, coastal, management strategy, policy

ARTICLE INFO

Article history:

Received: 03 February 2021

Accepted: 24 May 2021

Published: 31 July 2021

DOI: https://doi.org/10.47836/pjst.29.3.29

E-mail addresses:

afithor@gmail.com (Alin Fithor)

sbudiprayitno@gmail.com (Slamet Budi Prayitno)

frpurwanti@gmail.com (Frida Purwanti)

indarjoa@yahoo.com (Agus Indarjo)

* Corresponding author

\section{INTRODUCTION}

As a strategic port city, Semarang has natural resources offered to the city government for the central government to continue as an attractive new magnet. History begins in the 8th century AD, namely a coastal area called Pragota (now Bergota) and was part of the ancient Mataram kingdom. At that time, the area was a port and in front of it 
was a cluster of small islands. As a result of the deposition, which is still ongoing, these clusters are now coalesced to form the land.

According to regional governance, the definition of regional autonomy is the rights, authorities, and obligations of the autonomous region to regulate and manage government affairs and the interests of regional communities in the system of the Unitary State of the Republic of Indonesia. The beach tourism sector plays an important role in realizing the welfare needs of the community through recreation and travel and increasing state income to realize people's welfare. The beach tourism sector is a sector that can develop as a source of regional income.

The role of the city government in developing the existing and untapped beach tourism potential. Semarang City must be able to compete with other cities as a tourist destination, not only as a transit city but also as a national and international tourist destination. Other benefits obtained at once are the opening of job opportunities for the community, an increase in the beach tourism industry sector, and an increase in local revenue. The city government has made no effort to produce positive results, but the management of the coastal beach tourism sector is still considered inadequate compared to other regions. The community still lacks information about tourist objects and the lack of public facilities to support beach tourism activities. There are still many conditions for damaged and unkempt tourist objects and beach tourism preservation activities or events that are still less varied.

Broadly speaking, the role of government in beach tourism development is to provide infrastructure (not only in physical form), expand various forms of facilities, coordinate activities between government and private officials, regulation, and general promotion abroad. However, it also needs input from academia as part of development. The criticism and suggestions from this journal are to build a coastal beach tourism area with several recommendations to do at this time.

\section{LITERATURE REVIEW}

Coastal resources provide various environmental products and services that support various living needs and various economic activities. The potential of coastal recreation can give hope for the adequacy of the financial needs of people's lives, especially those living around the coast. The most formidable challenge is that the Semarang coastline's length occurs by jutting into the sea with significant changes every year (Bott \& Braun, 2019; Fithor et al., 2013).

Under the spatial planning and governance in the Semarang city government environment, Semarang's northern coastal area is worth making new beach tourism a magnet to increase tourists' number. The choices of resources become an essential matter that influences the direction of utilization. It means that utilizing the type of resources might require shifting to be raised into a new attraction (Brand \& Spencer, 2019; Liu et al., 2019). 
The requirements for developing a beach tourism location are human resources, access roads, infrastructure for coastal zones, and management policy (Wever et al., 2012). The management policy continues to develop the beach tourism area to support management wisely. The beach location can benefit Semarang as a provider of alternative beach tourism at affordable prices and bring a new attraction for beach tourism (Lithgow et al., 2019).

Various studies have multiple systems in life; decision-making considers providing a better perception and a more systematic approach in this study area. Decision-making can do in the field of human resources and management. Decision-making and selection processes become increasingly technical and automatically calculate the qualifications and rankings of alternative individuals by eliminating or minimizing the subjectivity of the decisions indicated (Artiningsih et al., 2016; Buchori et al., 2018).

Sholeh and Farid (2021) presented shared beach tourism that can be solved using an analytic hierarchy process analysis discussed in a more depth manner that has been proven very efficient in selecting and ranking processes. Thus, it uses as a calculation means in this study.

The maritime beach tourism sector is inseparable from the community and local government's participation as a regulator. This role can implement in various forms of the beach tourism service business. The existence of the potential of these natural attractions cannot develop optimally. This condition has become a valuable component, including ecosystems, communities, and socioeconomic risks under pressure from marine dynamics (Liu et al., 2019).

Various studies conducted but reviving the atmosphere of beach tourism locations' novelty seems not to have been studied yet. New attractions in management can be a management challenge. Marina Beach has now managed in a mature and integrated manner is the only coastal area managed directly by the Semarang City Government. However, the government has not managed other beaches, such as Maron, Tirang, Baruna, and Cipta. Therefore, the private sector's role can take over one or several coastal locations as an offer from the city government to the private sector, for there are many locations that might be new attractions in Semarang (Nurhidayah \& McIlgorm, 2019).

This study recommends wise management to build strategic locations to be new attractions to create a unique atmosphere and the latest offers to several beach tourism sectors in Semarang. Smart management requirements include 1) the principle of expediency to the leading industry and 2) Urban development policies equally developed indiscriminately.

\section{MATERIALS AND METHODS}

This study was conducted in the coastal area of Semarang City precisely as in the following map; namely several legendary beaches in the city of Semarang (Figure 1) (Sunaryo et al., 
2018). Good management can produce some visitors who can increase the beach tourism area, besides non-natural beach tourism in Semarang (Solihin et al., 2020).

This study is an evaluation made as a prospect of better utilization and management, especially in the area's control to better policies and provision of other coastal regions considered necessary for educational beach tourism.

This method uses a boxplot reading in the image to see the distribution of data where the maximum value, minimum value, quartile 1, 2, and 3, and extreme data will be visible. The advantage is that this application is open source and free of charge, complete output with visualization, and much of its use comes from the internet network. The weakness is that it is difficult for the ordinary person to do.

\section{Data Collection Method}

Data collected includes the average and characteristics of the tourist destination, including the number of samples divided into informants, the city government, the private sector, and visitors or tourists.

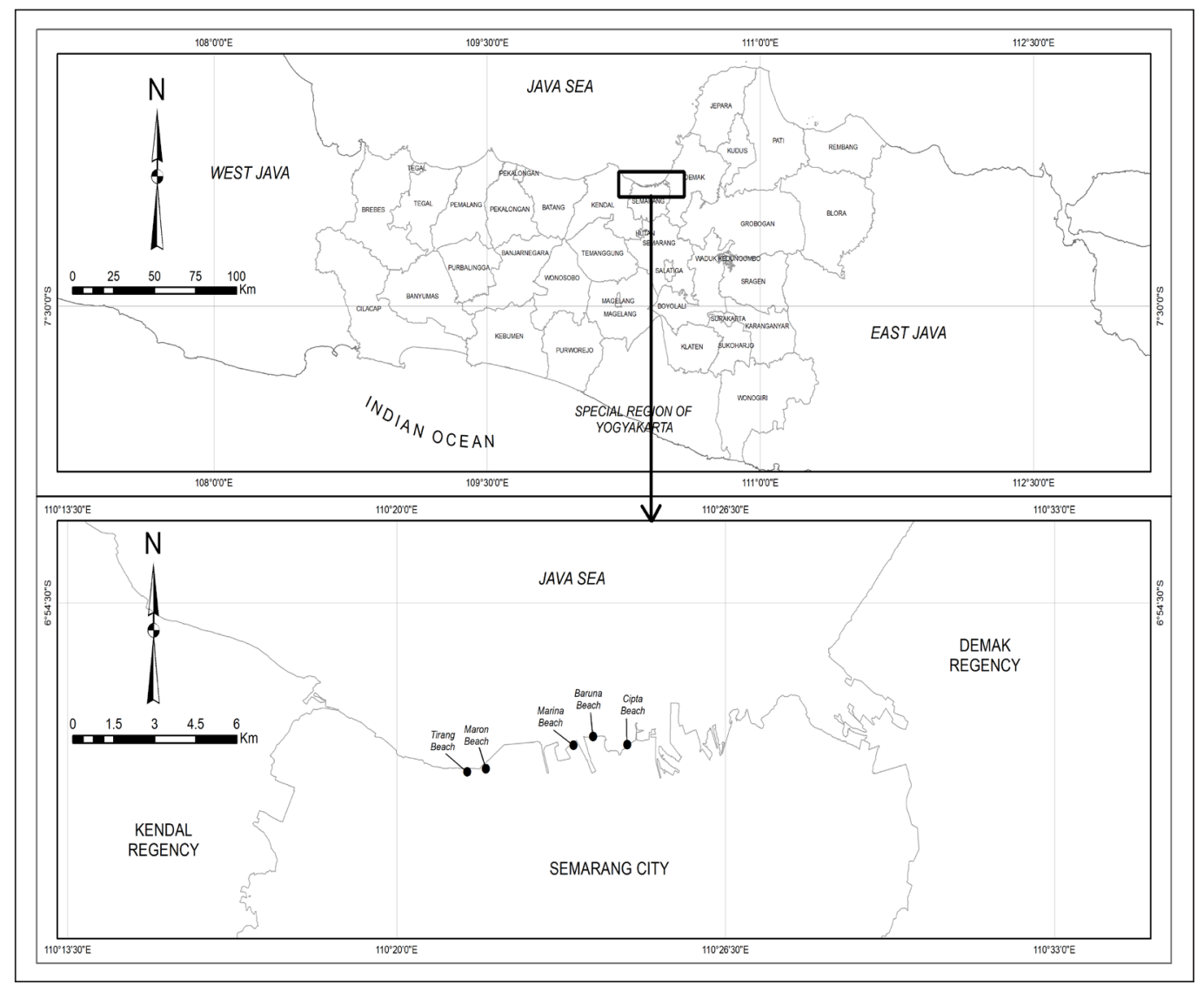

Figure 1. Research location 


\section{Types and Data Sources}

Primary data is data taken directly from the source that is a research object. The research item in materials and terms determines the best choice for having recreation (Dube et al., 2021). Secondary data is data taken indirectly from the source. In this final report, secondary data obtained from library books, scientific journals, papers, theses, and searching for information from the internet, which serves as the theoretical basis and complementary primary data, besides Table 1 below.

Table 1

Pairwise comparison scale

\begin{tabular}{cl}
\hline Intensity of Importance & \multicolumn{1}{c}{ Definition } \\
\hline 1 & The equal importance of both elements \\
3 & Weak importance of one element over another \\
5 & The essential or vital essence of one aspect over another \\
7 & Demonstrated importance of one factor over another \\
9 & The absolute volume of a component over another \\
$2,4,6,8$ & Intermediate values between two adjacent judgments \\
\hline
\end{tabular}

\section{Method of Collecting Data}

Rstudio is an IDE (integrated development environment) of the R programming language (Zheng et al., 2020). Steps to enter data into Rstudio:

1. Create a New Project in Rstudio, select a directory (e.g., E), then type the project name.

2. Insert the excel file into the same folder as the Rstudio project.

3. Import data directly using the 'import data' feature. Or you can type the code -library (readxl) - beach <- read_excel ("Pantai.xlsx", sheet = "according to which sheet will be analyzed")

4. Make sure you have installed the readxl packages; if not, you can type the code. install.packages ("readxl").

5. Make sure you are connected to the Internet when installing packages.

\section{Criteria and Alternative Assessment}

A scale of 1 to 9 is the best in expressing opinions on various issues. In this AHP, alternative assessment can do by the direct method (direct), the method used to enter quantitative data (Sholeh \& Farid, 2021). Considerations for pairwise comparisons to gain overall importance through the following stages, besides in Table 2 below. 
Table 2

The framework of the value evaluation and follow-up of the indicators

\begin{tabular}{ll}
\hline \multicolumn{1}{c}{ Indicator } & \multicolumn{1}{c}{ Criteria } \\
\hline A1. Security officer availability & Human Resources (A) \\
A2. Customer service availability & \\
A3. Cleaning service availability & \\
A4. Entrance ticket availability & Accessibility (B) \\
B1. Easy access for private vehicles & \\
B2. Easy access to public transportation & \\
B3. Ease of access with signage & \\
B4. Ease of access with expressway and railroad & \\
C1. Parking lot & \\
C2. Swimming pool & \\
C3. Kids garden & \\
C4. Jogging track & \\
D1. Rules or regulations related to studying tour groups ( C) \\
D2. Rules or regulation related to tourist-specific locations \\
D3. Rules or regulation related to an integrated location \\
D4. Rules or regulation related to management authority
\end{tabular}

\section{RESULTS}

This study found both government and private sector made similar evaluations. There was the role of visitors but only a little in terms of enjoying beach tourism objects. It should underline that Indonesia's policy manager always experiences a deadlock in management that often overlaps.

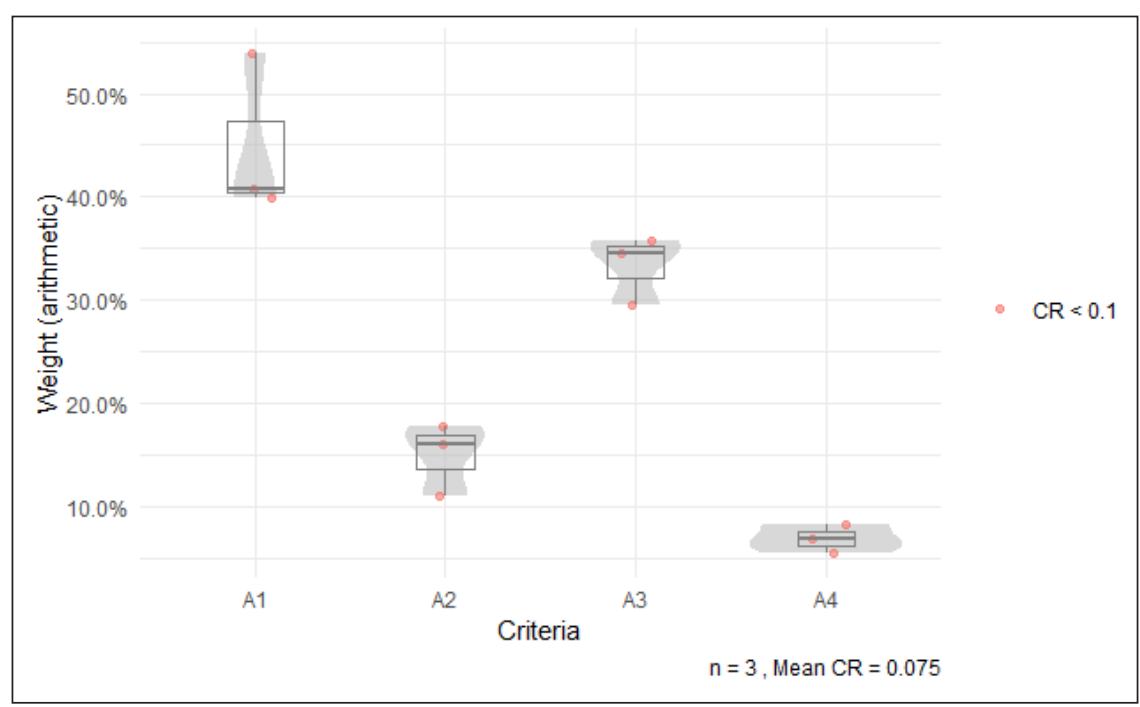

Figure 2. Boxplot RStudio for human resources - A 
In Figure 2, the boxplot shows that A1 criterion has the highest proportion of weight compared to other criteria. The boxplot position of each criterion follows the calculation of the weight proportion that has previously to obtain. The average CR is 0.075 .

Based on the priority value, in the A1 boxplot, the image shows a priority weight of $44.87 \%$, and below, the square image already represents, it can determine that the A1 criterion can select as a priority in making decisions - security guard - A1 needs for beach tourism object in Semarang. The moral responsibility of residents is still very lacking in terms of maintaining cleanliness. It has become the residents' bad habit. Convenience and some attractions affect several beaches, with moderate category values in management (Abbasi-Moud et al., 2021).

In Figure 3, the boxplot shows that the B3 criterion has the highest proportion of weight compared to other criteria. The boxplot position of each criterion follows the calculation of the weight proportion that has previously to obtain. The average CR is 0.107 .

Nurhidayah and McIlgorm (2019) ease access to signage is essential in collaboration with residents around the beach by placing object choices in Semarang's society. In the B3 boxplot, the image shows a priority weight of $52.88 \%$, and below, the square image already represents. Existing policies from the past few years need to be evaluated and improved according to the existing access. Analysis of tourist visits is required to manage without building new locations (Abbasi-Moud et al., 2021).

In Figure 4, the boxplot shows that the $\mathrm{C} 1$ criterion has the highest proportion of weight compared to other criteria. The boxplot position of each criterion follows the calculation of the weight proportion that has previously to obtain. The average CR is 0.144 .

In the $\mathrm{C} 1$ boxplot, the image shows a priority weight of $43.75 \%$, and below, the square image already represents. Furthermore, economic value is uncertain, but the government's

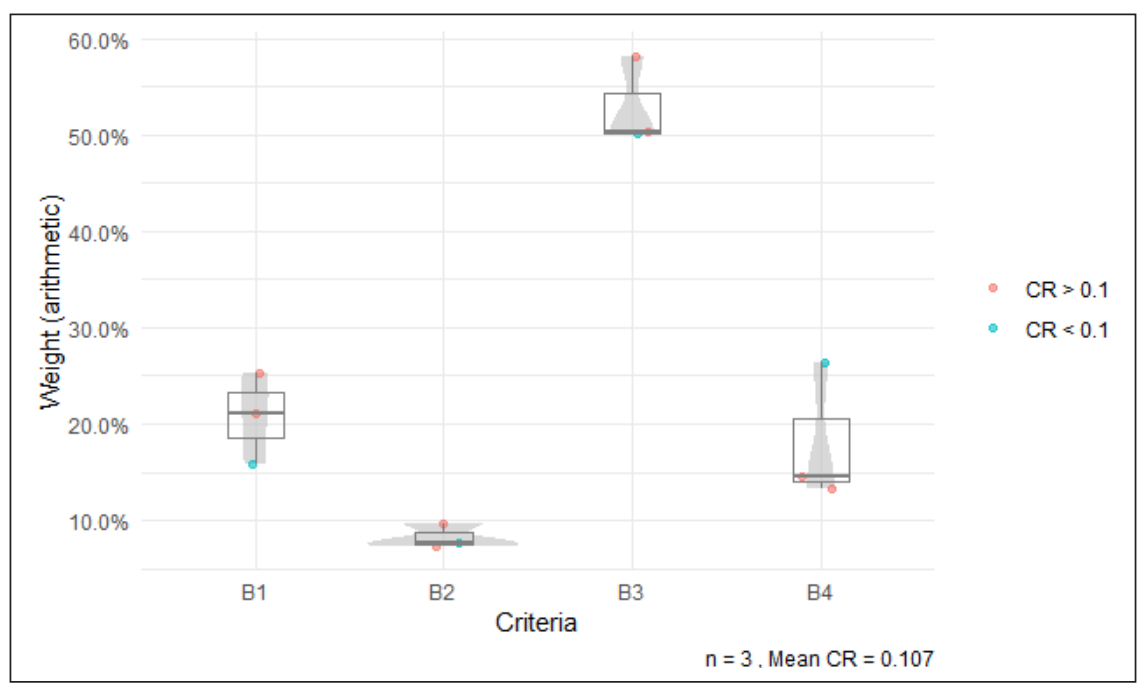

Figure 3. Boxplot RStudio for accessibility - B 


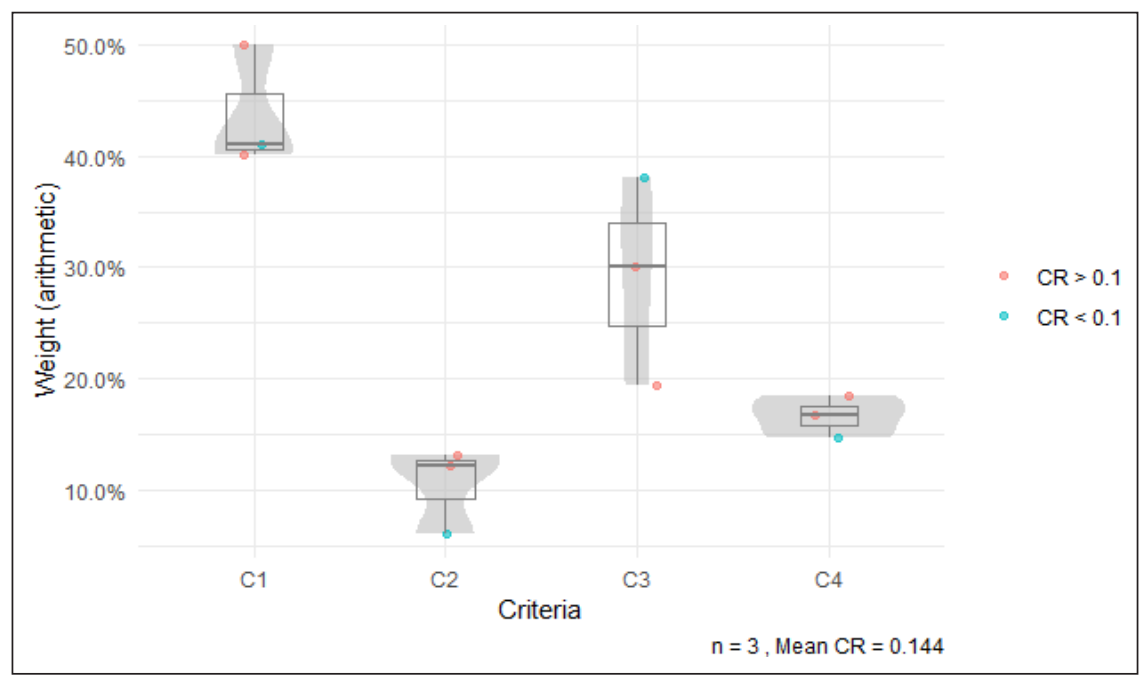

Figure 4. Boxplot RStudio for infrastructure - C

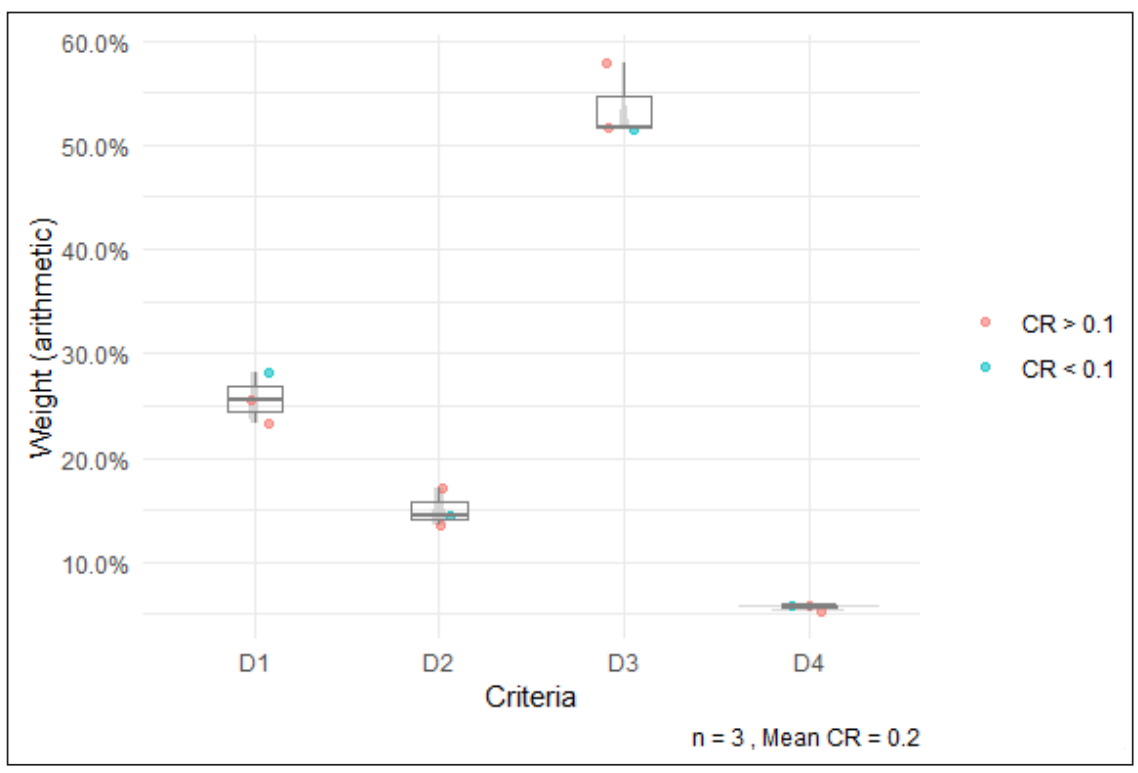

Figure 5. Boxplot RStudio For policy - D

relationship should raise economic value rather than regional expenditure income (Sunaryo et al., 2018). Just a Parking lot is undoubtedly an absolute beach tourism undertaking with third parties. It makes managers focus on beach tourism vehicles' security, provide entry tickets for treatment (not anyone who can manage it), and convenience in the tourist sites.

In Figure 5, the boxplot shows that the D3 criterion has the highest proportion of weight compared to other criteria. The boxplot position of each criterion follows the calculation of the weight proportion that has previously to obtain. The average CR is 0.2 . 
In the D3 boxplot, the image shows a priority weight of $53.66 \%$, and below, the square image already represents (Antunes do Carmo, 2019). The construction of the sea highway on the city's north coast has become a chance for the residents to make it easy to bring in tourists from outside Semarang (Artiningsih et al., 2016). The interview with the respondents, especially with the city leaders, might evaluate several beaches' current management concept, whether they are still following their land. New policies on the priority scale become a vital object to avoid misunderstandings (Aznar, 2021).

\section{DISCUSSION}

This study resulted in a new strategy in terms of beach recreation management. Instead of strengthening cooperation between individuals, prioritizing a new system might be better instead. The designs provide security personnel, free access to the coast supported by highways and railroads, plan parking lots and prioritize integrated management policies.

Those strategies expect to be a new strategy for refreshing the Semarang city government. Therefore, cross-sectoral cooperation is needed with one of the manifestations to divert the management of beach tourism areas in some of these beach locations belonging to the Semarang city government. Hopefully, this strategy also can be adapted to other beaches. The city government takes the following steps in implementing the following strategies.

\section{Planning}

Strategic planning that schedules development activities, all programs that support and create good community services, including efforts to improve the performance and capacity of the bureaucracy, management systems and utilization of information technology with policies directed at increasing tourist visits, improving the management of objects and beach tourism partnerships in the form of 1). Improve the performance of the apparatus; 2 ). Increasing the quality and quantity of beach tourism destinations; 3 ). Increase the number of foreign and domestic tourist visits; 4). Improve the facilities and infrastructure and event; 5). Increase the professionalism of human beach tourism resources (Sholeh \& Farid, 2021; Solihin et al., 2020).

\section{Organizing}

The findings show that city governments have limited human resources in carrying out their duties and functions. The ability to exist human resources is not optimal because not all of them know about beach tourism (Bott \& Braun, 2019). 


\section{Program Implementation and Implementation}

The field's findings reveal that having human resources who do not have an educational background in the beach tourism sector makes it difficult to optimize performance, while the beach tourism sector is a complex field (Dube et al., 2021; Sholeh \& Farid, 2021).

Findings in the field the implementation of strategies to improve the quality and quantity of beach tourism destinations is carried out by developing existing tourist destinations and searching for and exploring undiscovered potential beach tourism objects to become new tourist attractions. However, the implementation has not been optimal, as evidenced by the disappointment felt by tourists and business actors with the condition of facilities and access to several beach beach tourism attractions - the process of determining/developing a long attraction and the attitude of indigenous people.

The implementation of the strategy to increase the number of foreign and local tourist visits by adding several tourist attractions in various tourist objects and significant recurring events held every year. Implementation of beach tourism promotion and marketing activities essential in beach tourism development, making promotional materials, procuring promotional media at home and abroad. Collaboration with private parties, namely hotels and travel tours, in the form of an appeal to provide space for beach tourism promotion and offers of tour packages to tourist objects. However, behind the increase, in its implementation, a problem was found that was sufficient to increase tourist visits. The problem is branding, which tourists still know as a transit city, not a destination city.

Implementing strategies to improve the infrastructure to be less than optimal where there were complaints from tourists regarding traveling comfort, limited budgets, and lack of synergy between stakeholders and related service offices. However, efforts to recommend permits for tourist attractions, and fostering the implementation of beach tourism following the legislation, have continued to be carried out to results in satisfactory results where the number of hotels has increased on average and reached the targeted number.

This partnership-building activity program is scheduled and carried out regularly. In this activity, education on beach tourism gives to beach tourism business actors from the government by presenting speakers who are competent in their fields - carrying out the development of beach tourism activities, discussing the urgency of the problems found and solving problems, and finding the best solutions to overcome the problems experienced by beach tourism business actors. Training and coaching focus and order human resources engaged in the existing beach tourism sector by implementing such training, education, and coaching can help beach tourism human resources optimally and create HR professionalism.

\section{Monitoring and Evaluation}

To determine the extent to which the strategic plan requires evaluation activities annually, the government does not evaluate the strategy annually. The beach tourism management strategy is only a plan and does not work as it should (Bott \& Braun, 2019). 


\section{CONCLUSION}

Management consistency needs a more dignified beach recreation management frameworkthis the private sector's desire to manage new beach tourism to increase its income and employees. City governments must improve planning for area preservation, management, maintenance, and quality development of beach beach tourism areas. Improvements in the bureaucratic system to facilitate the planning process to increase the quality and quantity of beach tourism destinations must be more intense in coordination between related agencies to carry out activities to improve facilities and infrastructure in several coastal beach tourism. Making technological developments and globalization, providing more opportunities for the community to take an active role in beach tourism marketing activities by organizing creative activities so that people are more enthusiastic about beach tourism activities. Increase cooperation with the private sector by planning and implementing beach tourism activities involving the private sector to feel given a forum and support to participate in joint activities. Improve coordination with beach tourism activists and entrepreneurs. It enabled Semarang City's branding as a beach beach tourism destination by holding various promotional activities and beach tourism activists and entrepreneurs, conducting cooperation in coastal beach tourism management with the private sector.

\section{ACKNOWLEDGEMENTS}

This research received no specific grant from any funding agency in the public, commercial, or not-for-profit sectors.

\section{REFERENCES}

Abbasi-Moud, Z., Vahdat-Nejad, H., \& Sadri, J. (2021). Beach tourism recommendation system based on semantic clustering and sentiment analysis. Expert Systems with Applications, 167, Article 114324. https:// doi.org/10.1016/j.eswa.2020.114324

Antunes do Carmo, J. S. (2019). The changing paradigm of coastal management: The Portuguese case. Science of the Total Environment, 695, Article 133807. https://doi.org/10.1016/j.scitotenv.2019.133807

Artiningsih, Setyono, J. S., \& Yuniartanti, R. K. (2016). The challenges of disaster governance in an Indonesian multi-hazards city: A case of Semarang, Central Java. Procedia - Social and Behavioral Sciences, 227(November 2015), 347-353. https://doi.org/10.1016/j.sbspro.2016.06.081

Aznar, J. P. (2021). Differentiation and pricing strategies for hotels in sun and beach destinations. Managerial and Decision Economics, 42(2), 289-293. https://doi.org/10.1002/mde.3234

Bott, L. M., \& Braun, B. (2019). How do households respond to coastal hazards? A framework for accommodating strategies using the example of Semarang Bay, Indonesia. International Journal of Disaster Risk Reduction, 37(April), Article 101177. https://doi.org/10.1016/j.ijdrr.2019.101177

Brand, J. H., \& Spencer, K. L. (2019). Potential contamination of the coastal zone by eroding historic landfills. Marine Pollution Bulletin, 146(April), 282-291. https://doi.org/10.1016/j.marpolbul.2019.06.017 
Buchori, I., Pramitasari, A., Sugiri, A., Maryono, M., Basuki, Y., \& Sejati, A. W. (2018). Adaptation to coastal flooding and inundation: Mitigations and migration pattern in Semarang City, Indonesia. Ocean and Coastal Management, 163(July), 445-455. https://doi.org/10.1016/j.ocecoaman.2018.07.017

Dube, K., Nhamo, G., \& Chikodzi, D. (2021). Rising sea level and its implications on coastal beach tourism development in Cape Town, South Africa. Journal of Outdoor Recreation and beach tourism, 33(27209), Article 100346. https://doi.org/10.1016/j.jort.2020.100346

Fithor, A., Indarjo, A., \& Ario, R. (2013). Studi kesesuaian wisata dan mutu air laut untuk ekowisata rekreasi pantai di Pantai Maron Kota Semarang [Study of tourism suitability and sea water quality for coastal recreation ecotourism at Maron Beach, Semarang City]. Diponegoro Journal of Marine Research, 2(4), 31-35.

Lithgow, D., Martínez, M. L., Gallego-Fernández, J. B., Silva, R., \& Ramírez-Vargas, D. L. (2019). Exploring the co-occurrence between coastal squeeze and coastal beach tourism in a changing climate and its consequences. Beach Tourism Management, 74(January 2018), 43-54. https://doi.org/10.1016/j. tourman.2019.02.005

Liu, G., Cai, F., Qi, H., Zhu, J., Lei, G., Cao, H., \& Zheng, J. (2019). A method to nourished beach stability assessment: The case of China. Ocean and Coastal Management, 177(178), 166-178. https://doi. org/10.1016/j.ocecoaman.2019.05.015

Nurhidayah, L., \& McIlgorm, A. (2019). Coastal adaptation laws and the social justice of policies to address sea level rise: An Indonesian insight. Ocean and Coastal Management, 171(February 2018), 11-18. https:// doi.org/10.1016/j.ocecoaman.2019.01.011

Sholeh, M., \& Farid, A. (2021). Policy analysis of marine beach tourism of Gili Iyang Island, Madura, Indonesia. IOP Conference Series: Earth and Environmental Science, 674(1), Article 27209. https://doi. org/10.1088/1755-1315/674/1/012018

Solihin, L., Kusumastanto, T., Fauzi, A., \& Yulianda, F. (2020). Institutional arrangement of conservation areas for sustainable marine beach tourism in Gili Matra water beach tourism park, Indonesia. $A A C L$ Bioflux, 13(6), 3542-3555.

Sunaryo, S., Ambariyanto, A., Sugianto, D. N., Helmi, M., Kaimuddin, A. H., \& Indarjo, A. (2018). Risk analysis of coastal disaster of Semarang City, Indonesia. E3S Web of Conferences, 31, 1-5. https://doi. org/10.1051/e3sconf/20183112009

Wever, L., Glaser, M., Gorris, P., \& Ferrol-Schulte, D. (2012). Decentralization and participation in integrated coastal management: Policy lessons from Brazil and Indonesia. Ocean and Coastal Management, 66, 63-72. https://doi.org/10.1016/j.ocecoaman.2012.05.001

Zheng, W., Cai, F., Chen, S., Zhu, J., Qi, H., Cao, H., \& Zhao, S. (2020). Beach management strategy for small islands: Case studies of China. Ocean and Coastal Management, 184(July), Article 104908. https://doi. org/10.1016/j.ocecoaman.2019.104908 